\title{
Development of Project Assessment Instruments to Measure Science Literation Abilities in Integrated Learning at the Four Grade of Elementary School
}

\author{
Fiki Hermansyah $^{1^{*}} \quad$ Lilik Sabdaningtyas $^{2} \quad$ Pujiati $^{3} \quad$ Undang Rosidin $^{4}$ \\ Faculty of Teacher Training and Education, University of Lampung \\ St. Soemantri Brojonegoro No.1 Gedung Meneng Bandar Lampung 3514
}

\begin{abstract}
The purpose of this research is produce a project assessment instrument product to measure students' scientific literacy skills theoretically and empirically feasible on the theme of always saving energy. This research used research and development, refers to the theory of Borg \& Gall. The subjects of this research consisted of 6 students and 2 educators. The data collecting technique used expert validation questionnaire, practitioner questionnaire and students. The data analysis technique was carried out in a mixed manner between qualitative and quantitative. The results of this research indicate that the project appraisal instrument is feasible theoretically and empirically to measure students' scientific literacy abilities. The theoretical feasibility of the project appraisal instrument to measure students' scientific literacy skills is based on the assessment of 3 experts who obtained an average score of 81.43 in the "very good" category. The empirical feasibility of the project appraisal instrument to measure students 'scientific literacy skills was based on the teacher usability questionnaire which received an average score of 90.5 and the students' readability questionnaire obtained an average score of 89.6 in the very good category. Based on the results of all analyzes, it shows that the project appraisal instrument is suitable for measuring students' scientific literacy skills.
\end{abstract}

Keyword: Instruments, Project Appraisal, Science Literacy

DOI: $10.7176 / \mathrm{JEP} / 12-3-12$

Publication date: January $31^{\text {st }} 2021$

\section{Introduction}

Education is a necessity needed to improve the quality of human resources. The quality of education is largely determined by the learning process that occurs both inside and outside the classroom. Education in schools is an effort to bring students to a state of the process which is carried out not carelessly but a process that aims. One form of learning that can train students to carry out investigations in order to solve problems faced in real life is project-based learning. This is learning that organizes students to build their knowledge independently through indepth investigation to solve problems in a planned manner (Tseng, Chang, Lou, \& Chen, 2013). Improving the quality of education can be achieved through improving the quality of learning and the quality of the assessment system (Mardapi, 2012). : 12). Learning and assessment are inseparable parts of teaching and learning activities. Assessment is a major component in the duties and work of an educator. If educators are able to make good assessments, it can be ascertained that the educators have good teaching skills as well. This indicates that that if you want to be good educators, educators must have sufficient knowledge about assessment (Kusaeri, 2014: 14).

Assessment is the task of finding students' beliefs, strategies, strengths, and weaknesses in learning (Earl \& Giles, 2011). Assessment is an important component in learning, this is also important when scientific literacy is the main goal of learning (Shwartz, 2006). Assessment activities cannot be separated in the learning process. Assessment of learning outcomes is an effort or action to determine the extent to which the predetermined learning indicators have been achieved, assessment is also one of the activities carried out to measure and assess the extent of curriculum achievement. In addition, assessment can be used to determine the advantages and disadvantages of the learning process. Maba W. \& Mantra I.B's research (2016) shows that elementary school educators should use various assessment models based on aspects of attitudes, knowledge, and skills. Assessment of students' attitudes includes observation, self-assessment, peer assessment, and educator notes. Assessment of learners' knowledge includes written tests, oral tests, and assignments. Assessment of student skills includes performance, portfolios, and projects. Project assessment according to Majid (2014: 10) is an assessment of tasks that contain investigations and must be completed within a certain time. These duties include planning, implementing and reporting. The project will also provide information about the understanding and knowledge of students in certain subjects, the ability of students to apply knowledge and the ability of students to communicate information. Project assessment is highly recommended because it helps develop students' critical and creative thinking skills.

Scientific literacy according to Echols \& Shadily in Hilman (2015: 41) "Literally literacy comes from the word literacy which means literacy / illiteracy eradication movement. Science literacy according to PISA (OECD, 2006) is defined as the ability to use scientific knowledge, identify questions, and draw conclusions based on evidence, in order to understand and make decisions regarding nature and changes made to nature through human 
activities. Another definition views scientific literacy as multidimensional, not just an understanding of scientific knowledge, but more than that. Assessment of students' understanding of the characteristics of science as well as scientific investigation, awareness of how science and technology shape the material, intellectual and cultural environment, and the desire to engage in science-related issues, as reflective human beings. In line with the four pillars of universal education such as those formulated by UNESCO, namely "learning to know, learning to do, learning to be, and learning to live together" which makes students have to explore more of their potentials to be developed. Liu et al. (2011) which states that literacy skills are important to be analyzed according to developed countries such as the United States and China. According to the Chinese government, people with scientific literacy will be able to contribute to welfare both from social and economic aspects. So in developed countries, scientific literacy is a top priority in science education (Lau, 2009).

Regarding the results of observations made, the problem of assessment that often occurs in schools is the dominance of the use of written tests. The use of written tests can be in the form of multiple choice, matching tests, and essays are more frequently used. In fact, it is well known that the written test is a means of collecting assessment data. Making and using written tests is easy, causing educators to prefer this written test, rather than using authentic assessment which is more complicated in its manufacture and use. Assessment of the learning process of students in class is ignored, gets less attention compared to learning outcomes that are often done, namely the use of tests written. In particular, project assessment to measure students' scientific literacy skills is still very rarely carried out by teachers. Project assessment provides more opportunities for educators to recognize their students, because in reality not all students who are less successful in objective tests or essays can automatically said to be unskilled or uncreative. Thus the project assessment complements other assessments such as measuring scientific literacy skills for learning outcomes that are rarely done by educators.

The following are the results of the needs analysis obtained from distributing questionnaires from 10 educators about the project assessment instrument used to measure scientific literacy skills after preliminary research. Based on the results of the needs analysis questionnaire, it shows that $60 \%$ of teachers measure literacy skills, but only $10 \%$ show instructions for using project appraisals in books and $30 \%$ who understand how to develop assessment instruments. All teachers have not used project appraisals to measure scientific literacy skills and no teacher has developed project assessments to curate scientific literacy. Based on this, the researcher intends to develop a project appraisal instrument to measure scientific literacy skills in integrated learning in class IV of 1 Parerejo Elementary School. This is to improve the quality of the assessment instrument and the quality of students' scientific literacy.

\section{Method}

The research used Research and Development (R\&D), which adopted from the Borg and Gall model. According to them, R\&D is a development model that used to design new products and procedures that are field tested, evaluated, and refined to meet certain criteria. Conceptually, the research and development approach includes 10 general steps, as described by Borg \& Gall.

The subjects of this research were divided into two, namely the product trial subject and the use test subject. The subject of product trials is expert validation. The subjects of the used test were class IV teachers and students of SD N 1 Parerejo. This research was conducted in 1 class with a sample of 2 high-ability students, 2 moderateability students, 2 low-ability students. The object of research in this development research is a project appraisal instrument to measure students' scientific literacy skills.

\section{Results and Discussion}

\section{1 research and development of the Project Assessment Instrument to measure scientific literacy}

The results of research and development of the Project Assessment Instrument to measure scientific literacy skills in integrated learning obtained the following results.

\subsubsection{Research and Information Collecting}

The results of observations through preliminary research obtained data that: (1) Project assessment instruments in the teacher's book are still unclear and difficult to use. (2) The project appraisal instrument in the teacher's book does not yet contain clear assessment and scoring guidelines. (3) the teacher has never conducted an assessment using the project assessment. (4) Assessment of student learning outcomes is still focused on results not on the process so that students are still passive and less creative. (5) The skill process has not yet assessed scientific literacy. Based on the description above, it can be seen that there are potentials and conditions that support the development of project appraisal instruments to measure scientific literacy skills in integrated learning in fourth grade elementary schools.

\subsubsection{Planning}

At this stage, prepares materials and makes product designs. This planning stage begins with determining a theme, assessing core competencies, basic competencies, indicators, formulating materials, and compiling a grid of instruments to be developed. 


\subsubsection{Develop preliminary}

Product development is manifested in parts that have been planned to be compiled and designed so that it becomes an initial product draft including the initial stage of drafting an assessment instrument, there are 6 steps according to Subali, namely as follows: (a) mapping the instrument, (b) compiling a grid, ( c) compiling instruments, (d) analyzing to assess the quality of the instruments qualitatively, (e) testing measuring instruments. (f) implementation of measurement. The instrument mapping plan is modified by Nurgiyanto's (2013: 30) opinion, namely (1) determining standards, (2) determining project tasks, (3) making criteria, and (4) making rubrics. The design results in the form of a prototype are then validated by experts. Design validation is carried out by experts, namely material expert lecturers, evaluation experts, linguists, and practitioners.

Tabel 1. Results of Validation by Experts

\begin{tabular}{|c|c|c|}
\hline No & Validator & Nilai \\
\hline 1 & Material Expert & 79,17 \\
\hline 2 & Linguist & 88,46 \\
\hline 3 & Evaluation Expert & 76,66 \\
\hline \multicolumn{2}{|c|}{ Average } & 81,43 \\
\hline
\end{tabular}

Tabel 2 Results of Validation by Practitioners (Educators)

\begin{tabular}{|c|c|c|}
\hline No & Validator & Nilai \\
\hline $\mathbf{1}$ & S & $92 \%$ \\
\hline $\mathbf{2}$ & DYA & $89 \%$ \\
\hline & Average & $\mathbf{9 0 , 5 \%}$ \\
\hline
\end{tabular}

Based on tables 1 and 2.The results of the 3 expert validation test, namely (1) the expert material test obtained an average score of 79.17, (2) the validation test language expert received an average score of 88.46 and (3) the expert evaluation test obtained The average score is 76.66, in the validation test 3 experts are categorized as very feasible to use.

\subsubsection{Premilinary Field Testing}

The preliminary preliminary trial was carried out after expert validation, the initial preliminary trial was carried out by a small group to assess the feasibility of the product developed, namely in the form of a project assessment instrument to measure scientific literacy skills in integrated learning based on the responses of educators and students in class IV SDN 1 Parerejo. The number of respondents was two educators, namely one class IVA educator and one class IVB teacher. While there were six students consisting of 2 high category students, 2 medium category students and 2 low category students. The aspects assessed by students are the feasibility of content and language appropriateness, while what is assessed by educators is the feasibility of construction, language feasibility, and feasibility of writing rules.

Tabel 3. Results of the Value Questionnaire for Educators.

\begin{tabular}{|c|l|c|c|}
\hline No & \multicolumn{1}{|c|}{ Rated aspect } & Teacher 1 & Teacher 2 \\
\hline $\mathbf{1 .}$ & Construction & 18 & 19 \\
\hline $\mathbf{2 .}$ & Language & 12 & 10 \\
\hline $\mathbf{3 .}$ & Writing Rules & 14 & 14 \\
\hline & Total score & 44 & 43 \\
\hline & Maximum Score & 48 & 48 \\
\hline & Score Percentage & $92 \%$ & $89 \%$ \\
\hline & Score Range & $84 \%-100 \%$ & $84 \%-100 \%$ \\
\hline & Average Percentage & \multicolumn{2}{|c|}{ Very Good } \\
\hline & Criteria & \multicolumn{2}{|c|}{ Very } \\
\hline
\end{tabular}

The results of the usability test by educators showed that the mean value of 2 educators was 4.6 with a percentage of $90.5 \%$ belonging to the "very feasible" category. 
Tabel 4. Readability Value Questionnaire Results for Students at SD Negeri 1 Parerejo

\begin{tabular}{|l|l|r|r|r|r|r|c|}
\hline \multirow{2}{*}{ No } & \multirow{2}{*}{ Rated aspect } & \multicolumn{7}{|c|}{ Student } \\
\cline { 3 - 8 } & & 1 & 2 & 3 & 4 & 5 & 6 \\
\hline $\mathbf{1 .}$ & Instrument Contents & 16 & 16 & 15 & 14 & 14 & 15 \\
\hline $\mathbf{2 .}$ & Language & 16 & 15 & 13 & 13 & 13 & 13 \\
\hline & Total score & 32 & 31 & 28 & 27 & 27 & 28 \\
\hline & Maximum Score & 32 & 32 & 32 & 32 & 32 & 32 \\
\hline & Score Percentage & $100 \%$ & $96 \%$ & $87 \%$ & $84 \%$ & $84 \%$ & $87 \%$ \\
\hline & Score Range & $84 \%-100 \%$ & $84 \%-100 \%$ & $67 \%-83 \%$ \\
\hline & Percentage Mean & \multicolumn{7}{|c|}{$89,6 \%$} \\
\hline & Criteria & \multicolumn{7}{|c|}{ Very Good } \\
\hline
\end{tabular}

The results of the student readability test showed that the mean value of 6 students with high, moderate, and low abilities was the percentage included in the "Very feasible" category.

\subsubsection{Main Product Revision}

After the initial product design is carried out to find out whether there are still discrepancies or errors in the product design to be repaired and as improvements to the product to be developed. At this stage the researcher then corrects or revises the validated assessment instruments based on suggestions for improvements from the design validation. Looking at the results of the scores obtained by the validation and test experts in small groups, it can be concluded that the project assessment instrument for measuring scientific literacy was not revised and was feasible to be tested in the main field test.

\subsection{Discussion of Research Results}

\subsubsection{Development of Project Appraisal Instruments}

The development of a project assessment instrument to measure scientific literacy skills in integrated learning is focused on grade IV and adapting from the R\&D steps by Borg \& Gall (1983: 784) using five out of ten steps due to limitations in the current Covid-19 pandemic era. The first stage is research and preliminary information collection, after the researcher knows the problem that occurs the researcher plans to develop a project assessment instrument that will be used by educators to measure students' scientific literacy skills. Furthermore, the researcher compiled the initial product development of the assessment instrument, in this step the researcher drafted the assessment instrument referring to the 6 steps according to Subali, namely as follows: (a) mapping the instrument, (b) arranging the grid, (c) arranging the instrument, (d) ) studying to assess the quality of the instrument qualitatively, (e) testing the measuring instrument. (f) implementation of measurement.

\subsubsection{Project Assessment Instruments to Measure Theoretically Appropriate and Empirical Scientific Literacy Abilities.}

The results of this Research and Development show that the product of the project appraisal instrument is theoretically feasible to measure students' literacy skills. The development of project skills assessment instruments is based on the theory of project appraisal instruments so that the resulting products are more meaningful for students and teachers in terms of understanding project skills assessment instruments, because this instrument is an alternative assessment carried out to assess students authentically.

Furthermore, the process of developing the project skills assessment instrument goes through the validation stage by experts before the instrument is tested. This aims to determine whether the quality of the instrument is appropriate or not. Design validation was carried out by 2 lecturers as material, evaluation, and language experts who assessed three aspects: each aspect of the assessment was then interpreted into 4 categories, including the very good category getting a score of 4 , good category getting a score of 3 , enough category getting a score of 2 , and the less category gets a score of 1 .

Validation sheets from validator 1, validator 2, and validator 3, and expert practitioners show that the project appraisal instrument on integrated learning that is developed is suitable for use as an instrument in learning with several revisions of improvements, so that revisions must be made according to suggestions and comments from each. each validator first before moving on to the next stage. The validity of the project skills assessment instrument can be seen from each validator with the percentage of the assessment which shows the average percentage $>80 \%$. The results of the percentage show that each validator gives a score with the criteria "very feasible". The score of material experts was $76.66 \%$, linguists were $88.46 \%$, evaluation experts were $79.17 \%$, and practitioners were 100\%. According to Majid (2014: 10) project appraisal is an assessment of tasks that contain investigations and must be completed within a certain time. These duties include planning, implementing and reporting. The project will also provide information about students' understanding and knowledge in certain subjects, students' ability to apply knowledge and students' ability to communicate information. Project appraisal is highly recommended because it helps develop students' critical and creative thinking skills. Arikunto (2013: 3) adds that project appraisal is an assessment of an investigative process to find meaningful benefits for human life 
that must be completed within a certain time. Project appraisal is carried out starting from the planning, working process to the final project result.

Based on the results of the study, it shows that the project skills assessment instrument developed has advantages when compared to the skills assessment instrument contained in the teacher's book. The following is the difference between the performance appraisal instruments resulting from development with existing instruments.

Table 5. Differences in the Performance Appraisal Instruments developed with those in the Teacher

Book.

\begin{tabular}{|c|c|}
\hline $\begin{array}{l}\text { Project Assessment Instruments in Teacher's } \\
\text { Books }\end{array}$ & $\begin{array}{llll}\text { Product Assessment Instrument } & \text { Development } \\
\text { Results } & & & \\
\end{array}$ \\
\hline $\begin{array}{l}\text { The instruments are presented globally / in general, yet } \\
\text { the ability to be assessed is neither process nor product } \\
\text { detailed. }\end{array}$ & $\begin{array}{l}\text { The instrument is presented in detail about the } \\
\text { capabilities of the aspects being assessed, both the } \\
\text { process and the product. }\end{array}$ \\
\hline $\begin{array}{l}\text { Has not included instructions for use so the teacher has } \\
\text { difficulty using it }\end{array}$ & The instructions for using the book are clear \\
\hline Rubric is always the same in every lesson & The rubrics are more varied \\
\hline The criteria in the aspect assessed are not clear & $\begin{array}{l}\text { The criteria used are clear to assess student projects, } \\
\text { so they are easy to use. }\end{array}$ \\
\hline There & 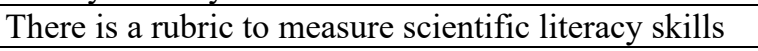 \\
\hline
\end{tabular}

Based on the differences in the table, it is clear that the advantages of the developed product are different, so that they have the potential to be used and continue to be developed in other themes.

Then in the next stage after the validation test is carried out, feasibility can also be seen in small group trials, based on the responses of educators and students, the number of respondents is 2 class IV educators. There were 6 students consisting of 2 students in the high category, 2 students with the medium category, and 2 students with the low category. Small group trials were carried out to assess the instrument developed in the form of an assessment instrument. The aspects assessed by students were content and language, while what was assessed by the teacher were aspects of the feasibility of the content of linguistic feasibility and presentation feasibility. The results of the usability trial by 2 investigators and the readability of 6 students, in this test the results were in the "very feasible" category. This response is in line with the results of Walsh's (2010) research on teacher pedagogical abilities regarding literacy which will have a positive effect in classroom learning.

According to Haryati (2007: 50) Project assessment as one of the learning evaluation models in class-based assessments that prioritizes project work, of course also has functions and objectives as well as several advantages over other evaluation models, including: a) Project work is an internal part of the standardized learning process, has pedagogic content and is meaningful for students, b) Provide opportunities for students to express their competences in full, c) More efficient and produce products that have economic value, d) Generate accountable competency mastery values.

Therefore, the use of project appraisal instruments is important to carry out in order to really know the students' abilities, especially the scientific literacy skills that the author will research, not only the results but also the learning process, so that there is no tendency for subjective assessments. Educators not only judge right and wrong answers without any reason, but educators must also assess the ability of students when practicing / skills during the learning process at home. The instrument developed has gone through several stages, starting from fulfilling the rules of writing instruments, validating theoretically and validating empirically. The results showed that each item in the project assessment instrument in integrated learning for grade IV elementary school students that had been validated by a team of experts was declared fit for use for measure the scientific literacy skills of students.

This research supports and continues the research of Lies Wahyuni (2018) who developed a project assessment model in the form of an assessment matrix or rubric only. The instrument developed has gone through several stages, starting from fulfilling the rules for writing instruments, validating theoretically and validating empirically. The results showed that each item of the project appraisal instrument in integrated learning for fourth grade elementary school students that had been validated by a team of experts was declared fit for use to measure students' scientific literacy skills. The result obtained from this research is a project appraisal instrument product in the form of an assignment. The product development has never been tested in a large group of products. The product is only based on the results of expert validation analysis and small group tests. So that it becomes a recommendation for further researchers to carry out the development to a further stage.

\section{Conclusion}

Based on the results of the research and development reports, it can be concluded that the product of the project assessment instrument developed is theoretically and empirically feasible to measure scientific literacy skills in integrated learning at the five grade of elementary school, especially on theme 2, sub-theme 4 . This is evidenced 
from the test expert validation from the assessment of 3 experts, namely material experts, evaluation experts, and linguists, who stated that the project assessment instrument developed was in the category of "very feasible". The teacher's usability test was carried out stating that the project appraisal instrument developed was in the very feasible category. In addition, this assessment instrument was also tested by practitioners on the responses of students with "Very High" results. Based on the results of the analysis of the project appraisal instrument carried out at the small group trial stage in the fourth grade of elementary school.

\section{References}

Arikunto, Suharsini. 2013. Dasar-Dasar Evaluasi Pendidikan. Jakarta: Bumi Aksara.

Borg, Walter R., dan Gall, Meredith Damien. 1983. Education Research. New York. 936 hlm.

Earl, K. \& D. Giles. 2011. Another Look at Assessment: Assessment in Learning. Journal of Teachers ${ }^{\text {ee }}$ Work, $8(1): 1120$

Haryati M., 2008. Model \& Teknik Penilaian Pada Tingkat Satuan Pendidikan, Jakarta : Mini Jaya Abadi

Hilman, Irfan. 2015. Mungkinkah Membangun Literasi Sains di SD/MI dengan Kompetensi Pendidik di Indonesia. Prosiding Seminar Nasional PendidikanDasar UPI. Vol 2

Kusaeri. 2014. Acuan dan Teknik Penilaian Proses dan Hasil Belajar dalam Kurikulum 2013. Yogyakarta : ArRuzz Media.

Lau, K. C. 2009. A Critical Examination of PISA' Assessment on Scientific Literacy. International Journal of Science and Mathematics Education, 7(1): 1061-1088.

Liu, O. L., H. S. Lee, \& M. C. Linn. 2011.Validating Measurement of Knowledge Integration in Science Using Multiple-Choice and Explanation Items Applied Measurement In Education. Journal of Educational Assessment, 16(3): 164184.

Maba W., Mantra I.B, 2016. An Analysis of Assessment Models Employed by The Indonesian Elementary School Teachers. International Journal of Social Sciences and Humanities, $\mathrm{Vol} 1$

Majid, A. 2014. Implementasi Kurikulum 2013. Bandung: Interes Media.

Mardapi, D. 2012. Pengukuran Penilaian Evaluasi Pendidikan. Yogyakarta: NuhaMedika.

Nurgiyantoro, Burhan. 2012. Penilaian Otentik. Yogyakarta : Gadjah Mada University Press.

OECD. 2006. A Framework for PISA 2006: Assessing Scientific, Reading, and Mathematical Literacy: OECD Publishing.

Shwartz, Y., R. B.Zvi, \& A. Hofstein. 2006. The Use of Scientific Literacy Taxonomy for Assessing The Development of Chemical Literacy Among High-School Students. Journal of Chemistry Education Research and Practice, 7(4): 203-225.

Tseng, K.H, Chang, C. C. S., Lou, J., \& Chen W. P. (2013). Attitudes towards science, technology, engineering and mathematics (STEM) in a project-based learning (Pjbl) environment. International Journal of Technology and Design Education, 23(1): 87 - 102.

Wahyuni Lies \&Ruhimat Mamat. 2018. Pengembangan Model Penilaian Projek untuk Mengukur Aspek Psikomotor. Jurnal Pendidikan Ilmu Sosial. Vol 27

Walsh, Maureen. 2010. Multimodal Literacy: What does it mean for classroom practice?. Australian Journal of Language and Literacy, 33(3): 211239. 